\title{
Entrevista: \\ Nicolau Sevcenko
}

\author{
Entrevistadores: \\ André Scholz \\ Anna Luísa Veliago \\ Fernando Jimenez \\ Nicole Fobe \\ Ricardo Cardoso \\ Úrsula Passos
}

Para um dos volumes da quarta edição da Revista Humanidades em Diálogo, entrevistamos o professor e historiador Nicolau Sevcenko. Graduado pela FFLCH-USP em História em I975, doutor pela FFLCH-USP em História Social, pós-doutor pela University of London em História da Cultura em I990, Nicolau Sevcenko obteve sua livre-docência em I992 pela USP sob o título Orfeu Extático na Metrópole.

O contato com o professor foi, desde o começo, bastante amigável e em clima de descontração e informalidade, por isso decidimos publicar a entrevista nos moldes nos quais foi realizada. O que temos aqui é um esforço de retrato fiel da tarde de 8 de julho de 2010 no escritório da Universidade de Harvard no Brasil, horas agradáveis que passamos com uma figura incrível que é o professor Nicolau. 
ÚRSUla - Na introdução de "Orfeu extático na metrópole", você fala do pouco apoio que teve em sua pesquisa dos órgãos de fomento, mas logo em seguida agradece à FAPESP e ao CNPQ. Qual o papel dessas agências para as ciências humanas no Brasil e quais os principais problemas que você vê no modo de financiamento das pesquisas?

NicolaU - Essas agências fazem toda a diferença do mundo. No caso paulista, é mais do que evidente como a USP anda movida a FAPESP, mais do que a qualquer outra agência. Não há como pensar pesquisa acadêmica sem uma agência financiadora que propicie os recursos para que o pesquisador possa se dedicar em tempo integral e, por outro lado, obtenha os materiais sem os quais a pesquisa não pode se materializar, seja em termos de recursos de laboratório, seja em termos de bibliografia, revistas, livros e a circulação em eventos de trocas de ideias e de intercâmbio técnico-científico, tanto no Brasil quanto no exterior e esse papel é decisivo. O Brasil tem muito a avançar em termos de ampliar os investimentos que se faz em ciência e tecnologia, na medida em que o mundo se torna cada vez mais assinalado por essa competição em torno de uma sociedade do saber, e quem tiver o maior e melhor patrimônio técnico-científico evidentemente tem a vocação de prevalecer sobre todos os demais. Mas àquela altura, quando fiz o livro, havia um debate sobre os critérios de distribuição desses recursos e aconteceu num contexto em que a FAPESP foi tendendo a transitar para uma posição que sempre teve um apoio geral aos projetos conforme os critérios dos estatutos com os quais a agência foi criada, para uma orientação mais para pesquisa aplicada e para uma conexão com práticas industriais e tecnológicas com as quais se pretendia, enfim... transformar o que podia ser uma agência científica em uma agência de fomento ao desenvolvimento, mas que são duas coisas diferentes. Acho que uma coisa não deve ser misturada com a outra. Isso começou a acontecer quando eu estava fazendo essa pesquisa, a natureza da pesquisa foi tal que ela foi vítima do preconceito na distribuição de recursos, eu fui preterido em bolsas que solicitei, experiências muito desagradáveis, porque vários dos meus orientandos com projetos foram renegados na FAPESP por critérios os mais questionáveis possíveis e, do meu ponto de vista, os mais equivocados possíveis, no sentido em que eram críticas que exigiam do projeto um alinhamento ideológico, o que eu acho que não tem nada a ver com a pesquisa científica, ou exigir uma espécie de conexão mais evidente com linhas de pesquisa já consolidadas, o que eu também acho que não é a vocação da instituição de pesquisa. Ela deve trabalhar com a liberdade científica dos professores e pesquisadores, deve estimular a criatividade que decorre dessa liberdade, em vez de pressionar no sentido de tornar mais robustos projetos que já estão em andamento e que, portanto, já têm inúmeras carreiras associadas. Nesse sentido, sendo mais uma espécie de 
cimento estabilizador do que de fato uma fonte de estímulo à multiplicidade, à diversidade, à multiplicação e diversificação da atividade técnico-científica no país. E essa é a crítica que eu embrionariamente implantei naquele prefácio e que mantenho até hoje. Acho que se havia cabimento em colocar aquele debate naquele momento, hoje em dia é ainda mais oportuno do que o foi naquela ocasião.

NiCOLE - Na sua aula, você consegue mesclar exatas, biológicas e humanas. Por que é tão importante para você a interdisciplinaridade?

NicolaU - Então, eu trabalho com história da cultura no período contemporâneo e obviamente, no período contemporâneo é que se deu a constatação dessa cultura tecnocientífica, porque na verdade o mundo passou a viver em função de uma tecnosfera, uma sociedade em que a interação de pessoas se faz por meio de recursos tecnológicos sofisticados, em que o cotidiano de cada um é marcado por esses recursos, as formas de integração produtiva que as pessoas têm nesse elemento de intermediação, e evidentemente, é no sentido de mais e mais diversificada difusão de recursos tecnológicos que a sociedade tende a caminhar nesse sentido. Portanto, é impossível entender o mundo contemporâneo sem saber o papel decisivo que tem a tecnologia e a maneira pela qual ela acaba condicionando a vida das pessoas, as maneiras de pensar, o imaginário, a sensibilidade, a percepção e assim por diante. Daí eu acho que se a gente não entende a tecnologia, não consegue entender a cultura, e aí não consegue entender o cotidiano. E é esse o meu empenho, esse o meu esforço. O ser humano continua a ser basicamente aquele que foi definido pelo processo evolutivo e nós estamos hoje no mesmo estado acabado em que os primeiros antecessores à nossa espécie se configuravam na savana africana. Desde então, continuamos o mesmo, nada mudou. No entanto, essa tecnologia foi crescendo ao nosso redor e produziu efeitos de aceleração, multiplicação de estímulos, de uma necessidade de atenção permanente, diversificada em diferentes níveis e em diferentes direções ao mesmo tempo. Isso tudo teve uma decorrência protética, no sentido em que acrescentou dotes que nós originalmente não tínhamos, então o que nós somos hoje não tem a ver com o que éramos originalmente. Ao mesmo tempo em que é algo que se sobrepõe algo, é que continua originalmente o mesmo. Portanto, é nesse jogo entre tecnologia e a nossa herança psico-físicobiológica que a gente tem que entender o que é o homem contemporâneo e quais são, portanto, as possibilidades de opção e as alternativas que ele tem para ou ceder a essa supremacia da tecnologia que se impôs sobre nós ou compreender que assim como o mundo nos dá certos potenciais, também tolhe outras formas de sensibilidades que poderiam ser muito mais ricas para a nossa vida cultural e social hoje do que simplesmente nos conformarmos a esse primado de uma 
civilização tecnocrática e tecnicista em que o sentimento, a sensibilidade, a percepção, as pulsões primárias têm um lugar cada vez menor e não produzem o efeito desejado, sobretudo da coesão social e do bem estar coletivo. A tecnologia dos estímulos vive para a produtividade, em vez de, como fundamentalmente deveríamos, para o prazer.

Nicole - Neste semestre não foi possível você dar aquela nova e prometida aula sobre Viena Vermelha, né? Então, ainda na tecla da interdisciplinaridade, qual seria a importância dessa aula específica nesse ponto e quais recursos você utiliza nessa aula? ${ }^{1}$

NiCOLAU - É difícil dar uma síntese breve disso, mas é um tema que me empolgou recentemente como parte da pesquisa que estou fazendo atualmente sobre o artista carioca Hélio Oiticica. Todo mundo meio que sabe quem foi o Hélio, o que ele fez e em geral o Hélio é julgado pelas obras que ele concretizou. Que não são obras que têm uma vida longa, são muito historicamente marcadas e elas também são muito existenciais, muito situacionais, no sentido em que elas não têm uma sobriedade de museu, uma sobrevida de arquivo, uma sobrevida de instituição. O Hélio era, sobretudo, anti-institucional e querer reduzir a sua vivência, a obra dele a uma conservação museológica é trágico. Eu acho que é a maior mágoa que podíamos lhe causar. É nesse sentido, então, que para entender o Hélio eu tentei entender o momento dele e por que ele fez a alternativa de ter escolhas tão ousadas, tão inusuais, tão escandalosas até no seu momento de vida. Porque me parece que elas tinham uma fonte mais profunda do que o momento específico em que estava vivendo. Isso me levou à pesquisa sobre a família dele que é incrivelmente notável no sentido em que o avô dele foi o mais importante líder anarquista do Brasil. Que inclusive comandou uma revolução anarquista no período ao redor da Revolução Russa, entre os anos I7 e I8, e planejou de fato uma tomada de poder anarquista no Brasil que só foi abortada porque no último momento foi infiltrada por agentes da polícia e seria curioso saber qual seria a história do Brasil se a revolução tivesse dado certo. De qualquer forma, ele depois disso vai passar a maior parte da sua vida madura preso. Foi preso durante os anos 20 por causa desse atentado, depois preso novamente durante o período getulista, porque obviamente era um dos críticos mais assíduos e radicais do governo ditatorial de Getúlio e obviamente seria depois preso durante a ditadura militar... O pobre homem, na verdade,

I O Prof. Sevcenko estava lecionando no primeiro semestre de 2010 a disciplina de História Contemporânea I no departamento de História da FFLCH-USP, porém, por motivo de tempo, não foi possível apresentar a aula sobre a Viena Vermelha, que ele considerava importante para a disciplina. 
teve um longo tempo livre pra escrever sua obra na prisão e é uma decorrência desse estado de coisas. A palavra anarquismo com o tempo se tornou sinônimo de baderna, de bagunça, de caos, eventualmente até de, valha-me Deus, desse terrível rótulo o mais indignante e desumano de todos, terrorista. Então, é uma palavra que é difícil de usar. Mas anarquismo na origem é um gesto de liberdade que tem a motivação de compreender que a existência flui de maneira orgânica, espontânea, se não for submetida a instituições centralizadoras. É simplesmente isso. Que a vida deve ser gerida a partir de grupos autônomos, de comunidades independentes, onde as pessoas tenham um status absolutamente idêntico e não haja a cristalização de nenhum sistema de poder. É simples assim. É isso que é anarquismo, nem mais, nem menos. Portanto, não tem nada a ver com violência, é antiviolenta, obviamente antiterrorista, antimilitarista, antiguerra, não quer fazer guerra. Não quer desencadear nenhum estado de violência que implicasse qualquer militarização da sociedade. Por essa razão, ele educou a família dele de uma maneira muito original. $\mathrm{O}$ avô do Hélio, que se chamava Hélio Oiticica, estudou Direito e abandonou no último ano, porque chegou à conclusão de que era uma instituição que, na verdade, fora criada para tolher o direito das pessoas e não para garantir. Ele fez medicina e abandonou no último ano porque compreendeu que a medicina, ao contrário do que se imagina, é um atentado contra a saúde coletiva, em vez de ser um sistema de garantir a preservação da saúde coletiva. E depois disso, nessa crítica ao Direito, nessa crítica à medicina, ele fez engenharia e abandonou, porque percebeu que a engenharia, em vez de planejar a vida coletiva para o bem-estar, planejava para o benefício de uma minoria privilegiada. Abandonou engenharia também. No final das contas, ele tem uma visão completa de todas as áreas decisivas desse mundo moderno, organizado tecnocraticamente e de como a tecnocracia funciona na verdade como um mecanismo, de sufoco, de opressão, em vez de uma forma de promover uma sociedade igualitária. E por isso é que ele se torna anarquista. Por uma confissão pessoal ele diz que veio a conhecer o método, o sistema anarquista e os autores anarquistas depois de já ter uma convicção de base que levava nessa direção, e ele educa os filhos dele dessa maneira. A ter uma vida saudável, vegetariana, que dispensasse qualquer contato com a medicina oficial, a ter um contato íntimo com a natureza desde a mais remota infância e ter um contato direto com comunidades, particularmente, comunidades de trabalhadores e, sobretudo, jamais à escola (risos de todos). Se quer adquirir a educação, nunca vá à escola! Porque na escola você perde a oportunidade de ter uma educação pra vida, você vai ter uma educação dirigida para aqueles que não são ligados ao seu destino, ao seu próprio pensar ou ao bem-estar das outras pessoas. E nesse sentido, o Hélio foi educado dessa maneira, nunca foi à escola e, no entanto, todas as tias dele, as irmãs do pai dele, eram artistas. A mãe dele foi uma grande música, pianista, uma grande intérprete. Outras irmãs eram 
artistas de teatro, músicas, bailarinas, poetisas. $\mathrm{O}$ avô dele era um grande poeta, um grande músico. O pai dele se tornou um naturalista, especializado em borboletas. Uma coisa impressionante: especializado na sensualidade das borboletas, na fauna tropical brasileira. E por conta disso ele levava as crianças, os três filhos, o Hélio e os dois irmãos, pra fazer excursões no morro da Tijuca e desde pequeno o Hélio se acostumou a se perder no meio da floresta, a andar descalço... enfim, esse contato profundo e íntimo com a natureza. Quer dizer, quando a gente tenta entender o Hélio, tem que entender esse pano de fundo. Quer dizer, não é uma pessoa normal que veio de uma situação normal. É uma parte da história do Brasil, que nunca fez parte da história oficial do Brasil. É essa parte de uma comunidade, uma cultura anarquista que a gente mal sabe ou desconfia que jamais existiu porque não está nos livros de História, a gente tem rara ou escassa informação, e é uma gente que pra ter esse estilo de vida sofreu terrivelmente, como esse homem que passou a maior parte da vida em calabouço. E aí, é claro, eu tive que entender essa fonte anarquista, de onde ela vinha e que espécie de rumo ela tomou ao longo do século XX, que fonte era essa em que o Hélio estava bebendo. O que me levou a tentar entender, sobretudo, o impacto que o anarquismo teve no contexto da cultura modernista e, como a gente viu no curso, quem estava no curso, na verdade o anarquismo está na base de todos os momentos decisivos da arte moderna. O núcleo dos anarquistas ao redor do Picasso é que criou a revolução da arte cubista, da poesia cubista, do teatro moderno do Alfred Jarry, da música do Erik Satie. E desse gesto cubista houve um desdobramento ainda mais radical nos procedimentos da colagem, quer dizer o grupo, todos eles anarquistas, tem paralelo no mesmo período antes da Primeira Guerra Mundial, a erupção da arte suprematista na Rússia prérevolucionária, por grupos anarquistas ligados à agitação revolucionária em estreita comunhão com a arte cubista de Paris. E eu não tive a oportunidade de falar desse momento da Viena Vermelha, que se encaixa de uma maneira muito surpreendente porque, pra dar um breve histórico, quando, com o fim da Primeira Guerra Mundial, os alemães e os austríacos se rendem incondicionalmente aos Aliados, eles impuseram medidas muito pesadas de indenização pros dois lados e, em particular, uma das iniciativas que o Aliados tiveram foi de fragmentar completamente o Império Austro-Húngaro, promovendo a emancipação das várias nacionalidades que o compunham. De modo que, o Império Austro-Húngaro, depois da primeira guerra, se transforma em uma dúzia de nações diferentes, sendo que uma única pequena parte de língua germânica fica como Áustria, exatamente o mesmo território que hoje se chama Áustria. E era uma pequena área que não tinha recursos naturais, não tinha petróleo, não tinha minas de ferro, de carvão... não tinha como sobreviver. E foi deixada à própria sorte, numa situação muitíssimo difícil porque depois da guerra, por conta das dificuldades da guerra e do bombardeio 
dos Aliados, grande parte dos refugiados de guerra do Império Austro Húngaro foi se abrigar na capital do Império Austro-Húngaro, em Viena, de tal maneira que Viena sai da guerra num tal estado de um imenso inchaço social, de uma população deficiente, de feridos de guerra, traumatizados de guerra, prisioneiros de guerra e desempregados de todos os tipos. Numa cidade que tinha escassa estrutura econômica e estrutura urbana para abrigar e garantir a sobrevivência de toda essa gente. Por conta dessa extrema instabilidade social, os comunistas vão tentar dar um golpe na Áustria, como tentaram na Alemanha, sobretudo na Baviera, em Berlim e Hamburgo, ou como tentavam, com algum sucesso também, na Hungria. O que levou o Partido Social Democrata da Áustria, praticamente centrado na cidade de Viena, antiga capital, para atuar como o principal agente de defesa da República da Áustria contra o golpe comunista. Quem garantiu a defesa da Áustria foram os Sociais-Democratas. Diferentemente do que ocorreu na Alemanha, onde os Sociais-Democratas se aliaram com as forças conservadoras filofascistas e com o exército para reprimir os comunistas e a repressão foi brutal e a República de Weimar nasce maculada por essa brutalidade repressiva encabeçada pela Social Democracia. No caso da Áustria, particularmente no da capital, Viena, os Social Democratas impediram o golpe, como era previsto, e impediram a guerra civil, e se tornaram os principais caudatários da estabilidade política da Áustria no pós-guerra. O que criou uma situação desequilibrada, porque o conjunto da Áustria, do país que ficou sendo chamado Áustria, é uma sociedade rural muito conservadora centrada na instituição da Igreja Católica. Viena apenas era o centro da atuação do Partido Social Democrata. Em compensação, praticamente Viena inteira era Social Democrata. E aí, na tentativa de estabilizar o país, fez-se um acordo entre as duas partes, Viena e os conservadores, para que os conservadores governassem a área rural e periférica da Áustria, enquanto a capital Viena era entregue ao governo Social Democrata e o governo Social Democrata se definia como radicalmente anticomunista e radicalmente anticapitalista e vai fazer uma profunda reforma social centrada na ideia da reforma urbana, e isso é particularmente relevante, porque ele vai inverter o sentido da reforma urbana herdada de Paris, da reforma de Paris em meados do século XIX, a reforma do Barão de Haussmann que é a mesma que vai ser difundida por todo o mundo e que vai marcar o modo como foi conduzida a reforma urbana no Brasil, atualmente Rio de Janeiro e São Paulo. Qual era o projeto dos Sociais Democratas? Era tentar criar um sistema de habitação de alta qualidade para as populações operárias na cidade de Viena, que garantisse a elas todos os serviços básicos, toda a infraestrutura necessária, para sobreviver naquele momento de crise e poder consolidar uma sociedade saudável, capaz de se reerguer, superando a crise do pós-guerra. Então, é fantástico porque eles começaram a aproveitar as áreas dos antigos castelos e das reservas florestais da aristocracia austríaca para 
criar grandes conjuntos de habitação operária, que foram desenhados por alguns dos arquitetos mais brilhantes da escola austríaca; e que se tornaram, na linguagem do período, como eram chamados pelos próprios trabalhadores, 'palácios do operariado'; e que não apenas comportavam os apartamentos com todos os recursos que as famílias precisavam para viver dignamente, mas tinham no centro de si todas as facilidades de médicos, dentistas, escolas, serviço social, enfermagem, atendimento às crianças, serviço de creche, serviço de treinamento profissional, alocação de empregos, serviço de qualificação educacional e profissional. Enfim, cada unidade daquela era uma megacomunidade criada no sentido de fortalecer as pessoas que ali viviam e dar a elas uma autoestima que lhes fizesse crer que elas não são o último bastião da sociedade, que elas são o próprio corpo da sociedade; e que a sociedade - para ser compreendida como uma sociedade humana - tinha que ser compreendida de baixo para cima, e não de cima para baixo. E todas aquelas pessoas teriam coparticipação na gestão desses recursos e coparticipação nas decisões sobre a distribuição dos orçamentos de Viena, no sentido de criar uma sociedade o mais igualitária possível para homens e mulheres com a preocupação, sobretudo, de cuidar das pessoas mais vulneráveis: as crianças que, àquela altura, morriam em quantidade por conta das doenças do pós-guerra - lembrem-se da gripe espanhola: a mortalidade foi brutal em Viena, onde as condições sanitárias eram hiperprecárias, com aquela multidão de gente que estava acumulada sem condições sanitárias e habitacionais adequadas -; proteção e alocação dos desempregados. Em particular, é fundamental no caso de Viena entender que com essa experiência social é que se consolidou o que se tornariam as escolas de psicologia dominantes no século XX: a psicologia sendo compreendida como uma ciência do bem-estar humano, uma ciência da autovalorização pessoal, uma ciência de reforço da subjetividade. O principal psicólogo, com todo respeito ao Freud, o pai criador da psicanálise - que embora fosse simpatizante do governo social-democrata de Viena, ele não tinha envolvimento direto - era um dos discípulos dele, o Alfred Adler - que depois migrou para os Estados Unidos para fugir dos fascistas e teve toda uma carreira nos Estados Unidos, mas é, infelizmente, pouco conhecido no Brasil - era o principal psicólogo envolvido no processo de criar uma ciência voltada justamente para erguer e consolidar essa autoestima das pessoas que àquela altura se achavam o último escalão da sociedade, pessoas que se consideravam socialmente degradadas e que tinham vergonha por não terem a cultura adequada, a educação adequada; e para dar a toda pessoa um atendimento que lhe permitisse reverter completamente essa percepção de si mesma e de entender o papel decisivo como elemento de uma comunidade viva, orgânica, em que todo mundo é absolutamente igual e absolutamente importante na mesma medida. E o impacto dessa forma de educação, sobretudo, nas escolas para as crianças: educar a criança desde pequena para conhecer o seu valor e exigir o 
respeito à sua dignidade pessoal e às suas aspirações pessoais. Então, é uma revolução cultural que veio de baixo para cima. Uma das dimensões era essa da autoestima e a outra dimensão obviamente era a do prazer, a da ideia de que o ser humano vive não para trabalhar, mas para viver e gozar a vida com seus iguais. Então, toda uma série de normas dos sociais-democratas convergiu no sentido de restringir ao máximo o tempo de trabalho e ampliar ao máximo o tempo de lazer; na verdade, criar uma cultura do lazer, em que ficava evidente que, para o social-democrata, o que era decisivo na sociedade não era o trabalho, o que era decisivo era o bem-estar, o lazer e o prazer, e só nesse momento é que a pessoa podia estar no máximo da sua subjetividade, no máximo da sua dignidade como ser humano. Isso foi completamente revolucionário. E o que me chocou - porque foi estudando as circunstâncias da família do Hélio que eu cheguei a essa pesquisa sobre Viena Vermelha - foi que os próprios analistas de Viena Vermelha começam sempre os seus trabalhos dizendo "é um escândalo gritante que se saiba tão pouco sobre a experiência de Viena Vermelha, mas é compreensível, porque no contexto dos anos 30 e 40 o mundo se dividiu em duas alas, comunistas e anticomunistas, e ambos eram odiados pelos líderes de Viena Vermelha e odiavam Viena Vermelha, então praticamente nenhum deles menciona Viena Vermelha e não deixa os órgãos de mídia comentar a experiência”. Então, o que se sabe é muito pouco, a documentação é muito pouca, e praticamente não está em nenhum livro de história; nem na própria Áustria, porque, evidentemente, depois que os fascistas destruíram Viena Vermelha, a educação voltou a ser o que era. A Áustria foi tomada pelos nazistas, foi nazificada, e criou-se uma espécie de bloqueio também para a compreensão e a valorização do que foi a experiência de Viena Vermelha. Portanto, mesmo nos países de língua alemã, é um assunto ainda meio tabu falar desse período e dessa experiência na Áustria. Só para dar o epílogo: evidentemente, a parte triste da história é que essa experiência foi tão radical e causou tanto desconforto diante dos conservadores da Áustria, sobretudo depois que a Alemanha foi tomada pelos nazistas a partir de 1932, que houve uma pressão geral para suprimir Viena Vermelha; e, graças ao apoio do partido nazista - que mandou armas e reforçou os conservadores a fazerem suas próprias milícias - as milícias fascistas da Áustria tomaram Viena Vermelha de assalto, bombardearam os condomínios operários, destruíram parte da arquitetura monumental, que simbolizava essa sociedade concebida de baixo para cima pelos sociaisdemocratas austríacos, e praticamente suprimiram Viena Vermelha da História, da mesma maneira como os comunistas vão suprimir os suprematistas da história da Revolução Russa. A Revolução Russa vai ser apresentada como uma revolução comunista, quando, na verdade, foi uma revolução de um amplo espectro de grupos políticos, com uma participação decisiva, fundamental, dos anarquistas; mas essa história foi reescrita depois que os bolcheviques suprimiram todos os 
demais grupos políticos e criaram uma construção monolítica, com o predomínio absoluto do partido comunista da União Soviética. Nesse sentido, o destino da Áustria Vermelha é muito semelhante ao que aconteceu no contexto da União Soviética, só que do ponto de vista do domínio nazifascista. Um último detalhe interessante é - e agora eu estou dando a aula que eu não dei como havia essa população gigantesca acumulada na Áustria - um crescimento demográfico por conta desses refugiados da guerra, desses soldados desmobilizados, e porque havia uma grande presença de prisioneiros de guerra, sobretudo russos, pois grande parte deles não voltou para a Rússia depois da guerra, mas ficou na Áustria, então a população era enorme - por mais que o partido social-democrata fizesse esses projetos de grandes comunidades de habitação operária, eram insuficientes diante da demanda para atender a todos, o que levou um enorme contingente, sobretudo de pessoas desempregadas, subempregadas, vítimas da guerra, aleijados de guerra, traumatizados de guerra, gente que não conseguia entrar no mercado de emprego, a criar todo um sistema de habitações espontâneas que se multiplicaram ao redor das fímbrias da cidade de Viena. Casas pequenas, que eram construídas com restos das ruínas da guerra, material que era acolhido das áreas vitimadas por bombardeios; construções precárias, mais ou menos agregadas em caixas, em conjuntos acumulados, dentro de um padrão de construção precária, improvisada, que a gente tende a chamar de 'shanty town', em inglês, ou 'favela', em português; de forma que essas casas, essas construções precárias, esses barracos proliferaram ao redor da cidade e, como essa população não estava na área de atuação de atendimento, de provisão do partido social-democrata, eles ficaram fora do partido e da vida partidária e criaram núcleos políticos próprios, espontâneos, que obviamente tinham uma permanente tensão com o partido social-democrata, porque eles estavam constantemente demandando atenções, serviços e oportunidades que o partido não tinha materialmente como lhes oferecer àquela altura. Essa gente, então, foi se radicalizando e assumindo um estilo de prática política extrapartidária de orientação anarquista ou anarquizante. E é nessas áreas que as experiências vão chegar ao seu clímax mais radical, porque na área em que prevalecia o partido social-democrata, havia certo limite para a ideia da autonomia do indivíduo: era a ideia de que o indivíduo tinha que colaborar com um projeto socialdemocrata da sociedade. O projeto era muito democrático, aberto, transparente, participativo - nesse sentido, era politicamente muito motivador - mas não há dúvida de que havia uma linha orientadora que era dada pelo partido socialdemocrata. Essa gente que ficou fora da cidade foi uma gente que não aceitava nenhuma política dominante, nenhuma linha como sendo uma fonte de inspiração coletiva: exigia estar numa posição em que pudesse pensar pela diversidade, em que pudesse pensar alternativamente as propostas do projeto do próprio partido social-democrata. E é nessas áreas que as experiências com 
psicologia mais radicais e as experiências comportamentais, existenciais, sobretudo da juventude, vão levar para o lado mais radical. Enquanto o partido social-democrata queria controlar festas, consumo de bebidas alcoólicas, danças - e achava que danças sensuais eram um mau exemplo americano - era exatamente esse estilo de vida que as pessoas vão ter nas periferias da cidade de Viena. E a experimentação sexual se torna obviamente descontrolada: enquanto o partido social-democrata concebia a sociedade como organizada em função da família nuclear e do controle dos adultos sobre os jovens, nessas áreas a liberdade era total em todos os níveis, de tal maneira que não havia qualquer entidade controladora ou qualquer espécie de ideia de tutela. Enfim, dessas experiências, se o Adler foi o psicólogo mais identificado com a área central de atuação do partido social-democrata, o Wilhelm Reich, o mais radical dos discípulos do Freud, é que era o psicólogo inspirador do grupo das comunidades externas, que eram chamadas, em alemão, 'comunidades selvagens'. Então, o Reich, o discípulo do Freud que propunha a total liberdade sexual e uma sociedade organizada pelo dispêndio da libido, tornou-se o inspirador dessas comunidades. Aí é interessante, porque o Adler e o Reich vão para os Estados Unidos depois, quando os fascistas invadem, e os dois vão ter uma vida muito trágica e vão ser obviamente massacrados pela sociedade norte-americana - o Adler, por ter essa orientação socializante, e o Reich, por ter essa orientação anarquizante - o que demonstra a inviabilidade do projeto de Viena Vermelha fora do contexto em que ele se deu historicamente. Por outro lado, todo o debate da psicologia e da ideia de liberdade individual que começa a vicejar, sobretudo nos anos 60, traz na raiz essa inspiração, tanto da psicologia adleriana quanto da reichiana, ou seja, da esquerda freudiana, e são elas que vão estar na raiz do projeto e da prática da libertação sexual que ocorreu de maneira esfuziante nos anos 60, até o revés do advento da AIDS e da sexualidade repressiva que a AIDS impôs revertendo-a. E coincide muito, porque a política radical dos anos 60 e meados dos anos 70 vai também atingir seu clímax em meados dos anos 70 e vai ser bloqueada a partir de 75 , sobretudo com a crise do petróleo e a ascensão do pensamento neoconservador, representado por Ronald Reagan e Margareth Thatcher. Enfim, todas as experiências políticas, de comportamento e de situações sociais e comunitárias autônomas vão ser praticamente bloqueadas de meados dos anos 70 em diante até os dias de hoje: um grande revés histórico. Mas esse momento do imediato pós-guerra é absolutamente fantástico, sobretudo, graças à maneira como a experiência de Viena Vermelha, que foi reprimida pelos nazifascistas, acabou ressurgindo no pós-guerra e em diante, como o Marcuse e o Fromm - ele é próximo aos frankfurtianos, mas não é membro direto da Escola de Frankfurt; a arte da liberdade, a arte de amar; o nome começa com F... Bom, é esse clima que o Hélio vivia no contexto da família dele: ele nunca teve desde pequeno qualquer 
sentido de autorrepressão ou de subordinação social; ele e os irmãos nunca foram para a escola e, portanto, não foram criados sob o sistema repressivo escolar, que impõe a cada aluno que se reduza à sua pequenez de 'mais um tijolo da parede', 'another brick in the wall'. Foram criados como gente em plena dignidade e na totalidade de seus potenciais desde pequenos; criados nesse contato íntimo com a natureza e numa vida cuja ideia é a de que você terá os seus melhores momentos no seu lazer, na sua interação emotiva e afetiva com as outras pessoas e no convívio direto com a natureza. Quando a gente pensa na obra dele, de onde saiu aquela coisa, aí você entende melhor: não é algo que surgiu com o clima dos anos 6o, é alguma coisa que veio do debate político, particularmente da parte do debate político que não é visível, da parte do debate político que foi abafada, suprimida, pela maneira como a Guerra Fria - o confronto, aliás, desde os anos 20, entre comunistas e anticomunistas - acabou impondo uma lógica dualista na qual não cabia alternativa. E o que essa gente representava, o que o Hélio representava, era exatamente um mundo pensado IO०\% fora desses dois trilhos, o do comunismo e o do anticomunismo, e numa ideia em que o ser humano é o centro. Não partidos, não sistemas, não burocracias, mas seres humanos: a felicidade do ser humano, o convívio do ser humano e o prazer que o ser humano pode ter, especialmente na troca com os outros.

RICARDO: É por isso que eu entendi o que os Parangolés significavam. Quando na mostra que teve em São Paulo ${ }^{2}$ eu fui vê-los pendurados, pensei : "Eu sempre ouvi falar disso, nunca entendi e continuo não entendendo". Dali a pouco, entra uma turma de crianças de uma excursão de escola e as monitoras tiram os Parangolés e os põem nas crianças. E as crianças saem mexendo com aquilo e se pegando uma com a outra e virando para lá e para cá e dali a pouco... três crianças com Parangolés e começam a se mexer juntas... Aí você vê aquilo se transformando e você fala "Essa é a arte plástica da vida". Não tem limite.

NicolaU: Glaro. E a criança, como não tem nada ainda controlando a cabeça dela, ela pira com aquilo. É a mesma coisa: quando ele fez as exposições dele no Rio ou em Londres ou em Nova York, quem detonava, quem entendia a proposta às últimas consequências eram sempre as crianças ou os muito jovens. Porque eles não têm nada ainda que diga a eles "tem que vir para cá, tem que ir para lá". Eles vão para todo lado. E aquilo lá é uma máquina de 'mandar para todo lado'. Você roda como um peão no meio daquilo.

2 Exposição Hélio Oiticica - O museu é o mundo que esteve em cartaz no Itaú Cultural de São Paulo entre 20 de março e 23 de maio de 2010. 
RicARDo: Quando você entra na tal Tropicália, no barraquinho da televisão, tem uma experiência sensorial incrível, porque você vê as cortininhas, vai entrando e de repente pensa "meu Deus, eu vou bater a cabeça". Aí você vai com a mão e sempre tem uma coisa em frente para você tocar, ou seja, é tudo muito calculado sensorialmente. Aí, de repente, você vê uma luz e você fala "bom, eu não vou bater a cabeça". Você segue a luz e dá num pequeno cômodo e constata que a luz é de uma televisão fora do ar. Você para, reflete, reflete, reflete, e aí você fala "agora eu vou voltar". Mas quando você vira para voltar, é outro caminho, porque as experiências sensoriais da volta são diferentes das da ida. É muito absurdo, é muito louco! E aí você fala "a vida é muito mais sensorial do que nos ensinam"...

Nicolau: E no projeto original do Hélio, ela é ainda mais radical. Não o deixaram fazer como ele queria, mas ele queria que, daquelas três barraquinhas, uma tivesse vaporizador de lança-perfume, outra tivesse vaporizador de maconha e a outra tivesse vaporizador de vinho. Então, o cara era completamente louco. E aconteceu isso: quando abriu a exposição - aqui no Rio não sei tanto, mas a de Londres foi superacompanhada pela imprensa - aquilo virou uma coqueluche da molecada. Acabava a escola, aquilo enchia para todo lado, e as crianças detonavam, rolavam na areia, faziam guerra de palha, rodavam com aqueles Parangolés, era uma loucura. O pessoal dos colégios de arte praticamente passou a morar dentro das instalações do Hélio. Então, quem fez a revolução lá foi essa juventude, esse pessoal que não tinha ainda nem I 8 anos e que entendeu totalmente a proposta, lá do lado do Polo Norte, quase no círculo polar ártico. Não precisa ser tropical para entender: tem a ver com o ser humano, não tem a ver com brasileiro.

Nicole: É dessa capacidade lúdica das crianças, desse mundo sem regras o seu fascínio pela Alice? É o mundo da Alice, não? A tradução ${ }^{3}$, imagino, demandou bastante tempo. O que você tinha em mente ao inserir alterações na sua versão?

Nicolau: Imenso tempo. O meu esforço nas traduções que eu fiz foi progressivamente tentar chegar mais e mais ao espírito do livro. E chegar ao espírito do livro não significa traduzir cada palavra exatamente como uma correspondência com o que está no original. Eventualmente, o que está no original não soa na língua portuguesa com o mesmo espírito: a língua inglesa tem

3 O prof. Sevcenko lançou pela editora Cosac\&Naify em 2009 uma tradução de Alice no País das Maravilhas, de Lewis Carroll. 
outra lógica, outra vibração, outra estrutura semântica, e as palavras têm pesos diferentes. Em particular, o Lewis Carroll escreveu não sobre qualquer criança, mas sobre crianças de uma elite, não tanto uma elite econômico-financeira, mas uma elite cultural, que é o meio social onde ele vivia, onde a família Liddell da Alice vivia: gente da comunidade acadêmica que, portanto, educava seus filhos de uma maneira muito elaborada, muito sofisticada. Então, Alice, por incrível que pareça, sendo tão criança, ela tem uma massa de informação que as crianças hoje em dia não têm da mesma forma. Então, o Lewis Carroll pode falar de grifos e Alice tem conhecimento perfeito do que é um grifo; mas para o Brasil é difícil imaginar uma criança que tenha compreensão do que é um grifo. E, no caso da Alice, também o livro retrata muito diretamente as experiências na própria cidade de Oxford, porque ele vivia ali, a família da Alice vivia ali, as crianças viviam e estudavam ali. Então, ele faz passeios e percursos com as crianças pela cidade, pelos jardins, pelos arredores, pelos rios, e ele vai fazendo referência ao que eles encontram naquelas áreas: animais que eles encontram ali - que, portanto, não têm a ver com a fauna brasileira - estátuas, ícones da arquitetura e dos monumentos urbanos da cidade - que são referências históricas da cultura renascentista ou da cultura vitoriana do século XIX. E tudo isso é muito familiar para ele - o livro reflete isso de uma maneira muito transparente - mas é algo que para nós não tem a mesma ressonância. Então, você tem que ficar meio que compondo. E ele faz diferentes registros de falas. Na Inglaterra, é muito evidente: as pessoas se distinguem muito pouco na aparência. É uma sociedade puritana, então todo mundo se veste com muita sobriedade. Não discrepa muito a maneira como uma pessoa muito rica se veste com relação à maneira como uma pessoa mais pobre se veste. Então, pela aparência você não distingue muito a classe social de uma pessoa. Gente muito rica, ao contrário, tende a ser extremamente sóbria para não ostentar. Do ponto de vista puritano, é um crime moral você ser ostensivo. Então, as pessoas se vestem deliberadamente com extrema simplicidade. E aí fica muito difícil você criar um registro social meramente pela avaliação externa da maneira como as pessoas se vestem, ou da postura, ou da fisionomia, ou da textura da pele das pessoas, porque ela é muito homogênea para todas as classes sociais. Você só conhece uma pessoa da Inglaterra quando ela abre a boca. Aí você sabe o sotaque, de que região a pessoa veio, que nível de escolaridade a pessoa tem, que classe social a pessoa tem, se ela é operária, se ela é camponesa, se ela mora no arredor da cidade. Enfim, você sabe absolutamente tudo pelas três primeiras palavras que a pessoa pronuncia. Então, a coisa da fala é muito forte. E você vai vendo a distinção dos diferentes personagens de Alice pela maneira como ele articula o vocabulário e pelas expressões vernaculares que as personagens usam. Aí para fazer uma adaptação disso para o português é uma luta férrea. Você vê personagens com as quais ele tem mais simpatia, outras com as quais ele tem menos simpatia. E também é 
muito difícil, porque ele cria essa simpatia ou essa antipatia pelo repertório linguístico que ele escolhe para se referir às personagens ou pelas palavras que ele põe na boca das personagens. E nem sempre é fácil. Por exemplo, fica evidente que a rainha é hostil, hipócrita e arrogante, mas em outras personagens isso tudo fica muito mais sutil, e você luta desesperadamente para tentar chegar ao espírito e achar as palavras em português que possam de alguma maneira trazer esse eco e a percepção para o leitor desse universo moral que o Lewis Carroll está compondo. Então, é um desafio permanente, mas é um jogo muito bonito, muito agradável de fazer, muito emocionante. Eu trabalhei demais nessa tradução, mas cada segundo desse trabalho, para mim, foi um ganho na minha vida, foi uma aventura empolgante. E, se ainda tiver oportunidade, faço outra versão.

\section{NiGOLE: Sobre esse papel do Lewis Carroll como incitador, o que queríamos saber é se o intelectual hoje ainda pode ter esse papel, já que assistimos cada vez mais à sua desvalorização.}

Nicolau: Então, de fato, o caso do Lewis Carroll é exemplar. Porque se você avaliar a pessoa do Lewis Carroll, para qualquer um de nós aqui no nosso momento atual, ele seria o protótipo daquilo que a gente define por 'careta'. Ele vivia num meio muito conservador, ele era membro do clero anglicano, foi ordenado no clero anglicano, e era membro da cúria da Universidade de Oxford. Nesse sentido, ele tinha todos os sinais exteriores de um homem muito conservador, pela maneira como ele se vestia, pelo repertório linguístico dele, pelos modos, pela educação, pelo comportamento; em todos os sentidos, ele é o padrão mais conservador da sociedade inglesa. Esse é o homem. Aí você vai ver o intelectual. No contexto da universidade, as pessoas o conhecem por essa exterioridade. Agora, quando ele atuava intelectualmente é que estava a grande diferença. Na verdade, como membro do corpo docente de Oxford, ainda havia uma particularidade interessante: ele era o responsável por cuidar da adega dessa Universidade. As universidades inglesas, como toda universidade europeia, tinham um desdobramento da Igreja, de uma instituição monacal; e toda instituição monacal, como era tradicional, sempre tinha uma adega, muito bem cuidada, com vinhos de alta qualidade. As universidades de Oxford e Cambridge até hoje mantêm adegas com excelente produção de vinho, com excelentes licores. Ele tinha essa responsabilidade enorme de zelar por aquele acervo, e era ele quem municiava as festas, os encontros. Então, quando ia ter algum evento, as pessoas iam "por favor, queríamos que houvesse algum vinho, algum licor ou algum uísque" e ele era que decidia o que seria servido, quanto seria servido. E, evidentemente, alguém às vezes fazia um ataque inesperado à adega dele, e ele lutava bravamente para defender (risos). E, é claro, também 
havia as conversas de que ele era o maior consumidor da própria adega. Enfim, esse é um dos lados peculiares da vida do Lewis Carroll. Mas, o mais notável, obviamente, é como intelectual. A gente só o conhece como autor da Alice, mas como matemático ele utilizou o extraordinário e sofisticado conhecimento matemático que ele tinha para uma aplicação até hoje mal compreendida, mal conhecida. Ele criou equações para definir em grupos colegiados que tomam decisões - grupos legislativos ou grupos executivos - como criar situações para que haja a maior equidade possível entre os membros constitutivos do corpo colegiado e entre os diferentes grupos sociais no conjunto da sociedade inglesa, de tal maneira que os grupos pudessem ser o mais representativo possível em relação à sociedade e o mais representativo possível em torno da equiparidade dos membros sem que algum possa prevalecer em relação aos demais. Então, ele fez uma representação matemática complexíssima de como quantificar e como organizar numericamente a participação colegiada em processos decisórios, o que é um esforço para promover uma democratização por uma consciência tecnocientífica, posta a serviço de uma sociedade mais igualitária, mais fraternal. Esses projetos do Lewis Carroll só foram mais bem compreendidos no começo do século XX e foram aplicados, sobretudo, depois da guerra - quando se criou a Liga das Nações, depois da Primeira Guerra Mundial, e depois a ONU, na Segunda Guerra Mundial - e são até hoje base do modo como se operam os procedimentos de decisão em corpos colegiados, em especial com muitos membros participantes. Esse é um lado de como ele usou a competência tecnocientífica dele para promover a democracia. Outro lado mal conhecido do Lewis Carroll é que ele foi um profundo defensor dos direitos dos animais. Ele escreveu vários libelos vociferando contra a prática da vivissecção nas universidades britânicas e denunciando como desumanidade gratuita a difusão dessa prática pelo sistema de ensino; enfim, no limite, denunciando toda e qualquer forma de exploração e abuso dos animais, como semelhante a toda forma de exploração e abuso de seres humanos, por exemplo, as populações coloniais submetidas ao império britânico. Nesse sentido, é um intelectual militante, extremamente ativo, e com ideias que a gente definiria hoje como ideias de esquerda - muito mais do que apenas liberais, eu diria até libertárias. Aí, quando você vê a Alice à luz dessa militância intelectual dele, você vê que a Alice traz esse conteúdo todo, porque é uma história centrada numa criança que não reconhece nenhum tipo de autoridade, nenhum tipo de poder acima do que é a sua própria dimensão de dignidade e de autoestima. Ninguém pode se sobrepor a ela por um título, ou por uma posição, ou por ser maior do que ela, ou por estar em maior número. Ela sempre faz que o diálogo convirja para uma situação em que as personagens se contraponham de igual para igual, indiferente ao fato de que ela é uma criança ainda em idade pré-escolar. Nesse sentido, ela nivela o universo inteiro por essa espécie de padrão de uma mentalidade 
completamente livre que ainda não incorporou as hierarquias, os preconceitos, as precedências e as múltiplas regras que impõem situações de desigualdade. Portanto, um modo de ver a sociedade de baixo para cima, de forte inspiração anarquizante. Eu acho que em toda a carreira intelectual do Lewis Carroll nada é mais radical do que Alice no País das Maravilhas, nesse sentido.

Anna: Sobre a leitura que fizemos do Orfeu Extático na Metrópole, surgiu uma questão: Como é possível conciliar os movimentos coletivos na cidade com a busca onírica do indivíduo? Em que medida a coletividade pode emancipar ou anular o indivíduo?

Nicolau: É uma leitura muito perceptiva, é exatamente essa a minha intenção no livro. Os anos 20 são o momento em que se articulam os chamados partidos de massa'. A gente sai de um modelo de prática política centrada no domínio das elites organizadas - o período que a gente chama de Primeira República, em que os partidos republicanos representavam basicamente os grupos lutocráticos dos diferentes Estados e regiões do Brasil - para uma situação em que começam a surgir os primeiros partidos que tentam articular dimensões corporativas, que englobam grupos sociais mais amplos - classes médias, operariado, e assim por diante. A impressão que esse tipo de articulação daria é que se caminha no sentido de uma democratização cada vez maior, já que você está saindo de uma política de vocação elitista para uma política de vocação mais ampla e difusa. Mas isso pode ser um ledo engano, porque uma das formas de organizar política de massa é o fascismo, outra forma de organizar política de massa é o comunismo. Então, é exatamente esse o quadro que você vai ter a partir do final da Primeira Guerra Mundial, e em especial com a Revolução Russa. O modelo do partido bolchevista, que domina o processo revolucionário e se impõe como autoridade absoluta na União Soviética, é que vai servir de inspiração para a organização dos partidos fascistas. Por incrível que pareça, a grande fonte de inspiração política do Hitler era o partido bolchevista russo. Então, simultaneamente você vê essas duas formas de política autoritária, brutal, repressiva, violenta, compondo-se sob o nome de mais democráticas do que a política anterior - democráticas, no sentido de que demograficamente elas têm uma expressão maior, mas elas são infinitamente mais brutais, no sentido da sua verticalidade, da sua militarização, do que a política liberal do período anterior. Uma das reações contra isso é justamente a dos grupos anarquistas, que tanto denunciavam a política elitista anterior quanto o autoritarismo comunista quanto o autoritarismo nazifascista. Mas, como nós sabemos, não se fez uma história do anarquismo. $\mathrm{O}$ anarquismo virou um xingamento, uma forma derrogatória de você se referir a adversários políticos que você quer desmoralizar. Não há propriamente uma história do anarquismo como prática política legítima na nossa historiografia, na nossa 
história da cultura política do ocidente. Então, esse era o paradoxo. Você está vendo uma sociedade em que a difusão da tecnologia converge no sentido de promover esse sentido de democratização e integração, mas estas pessoas sendo integradas na metrópole urbana são submetidas a essas novas estruturas políticas infinitamente mais repressivas e brutais do que as anteriores e esse era o paradoxo que eu queria estudar no livro. Eu tomava como referência naturalmente a semana de arte moderna de I922, que é tida como uma revolução estética liberalizante nos códigos culturais no Brasil, e o que eu queria demonstrar é que não, que ela se alinha com esse lado autoritário repressivo e nesse sentido, em vez de liberalizar, ela é muito mais sufocante do que o clima político vivido no período anterior à guerra e anterior à semana de arte moderna, se a gente pensar em gente como Machado de Assis, como Lima Barreto ou como João do Rio, para pegar apenas três exemplos. E os compromissos da semana de arte moderna e da estética do modernismo com o lado mais conversador e retrógrado do partido republicano paulista que eventualmente iria se desdobrar na elite que convergiria para o compromisso com a ditadura varguista. Por isso, eu terminava o livro com o discurso de posse do Getúlio Vargas depois do golpe que foi escrito pelo Cassiano Ricardo, membro do grupo organizador da semana de arte moderna, e, portanto, fazendo a ponte entre a semana de arte moderna, a política conservadora paulista, o Getúlio Vargas e esse clima repressivo, em vez da tradicional concepção liberalizante que a semana de arte moderna criou, muito porque os próprios participantes e herdeiros da semana de arte moderna que fizeram a historiografia deste movimento, e, portanto, deram a ele a imagem positiva que ele tem até hoje, que se reflete nos livros didáticos, na maneira como eu fui educado, por exemplo, e a compreensão da semana que eu tive no meu processo de educação.

RicARDO: Professor, você escreveu Literatura como Missão nos anos 80 falando sobre repressão. Tinha também em mente a repressão da ditadura? Além disso, o Orfeu não está muito distante deste primeiro nem no tempo cronológico em que foi escrito nem no recorte de tempo histórico. Como você vê hoje o momento em que os dois livros foram escritos?

NicolaU: Quanto ao espírito, você tem toda razão, é o mesmo e, é claro, ambos são dois livros escritos por alguém cuja experiência de formação e amadurecimento cultural e educacional, intelectual se fez sob a ditadura. Sou a legítima criatura da ditadura, do sistema educacional imposto pela ditadura, aquilo que o professor Antônio Cândido definiu como 'a geração sem palavras', porque eu fui criado e educado sob o sistema da censura e do cerceamento do acesso a todo tipo de informação que era controlado pela ditadura, e compreendo a razão do professor Antônio se referir a essa geração como a 'geração sem palavras', porque de fato 
éramos gente completamente reprimida, tolhida, travada, impotente diante daquela circunstância obscurantista no momento mais rico da vida de qualquer ser humano que é a sua juventude. É o momento em que você mentalmente, emocionalmente, sensorialmente, explode para a vida, e você não ter espaço para vida, e você não ter espaço para explodir, não ter estopim, combustível para explodir é uma crueldade trágica que as ditaduras fazem, consumindo a juventude e condenando tão precocemente a um estado de marasmo a parte mais criativa e promissora da sociedade. Então, eu vinha sem dúvida com esse peso. Quando eu fiz o trabalho sobre a primeira república, o Literatura como Missão - é claro que quando você escreve você não sabe porque está escrevendo, depois que você escreveu e o trabalho começa a ter repercussão e as pessoas começam a lhe dar interpretações que falem sobre o seu trabalho e você se põe na posição de pensar sobre ele a partir de fora, uma espécie de metarreflexão, ai é que você tenta entender o que está por trás, o que é que o motivou para fazer a análise e a argumentação daquela maneira - e me parecia exatamente isso, eu tentava entender um grupo de intelectuais que tinha a visão mais apurada, a visão crítica mais sensível e profunda a respeito da realidade do país, e que, no entanto, não tinha a menor chance de expor publicamente, não tinha a oportunidade de ser considerada como parte da interlocução política dominada por grupos conservadores de tendência autoritária e obscurantista também. Então eu via, no fundo, na primeira República, uma situação muito semelhante àquela que eu vivia sob a ditadura militar e via da perspectiva da tragédia do intelectual que vê o seu potencial renegado, recusado, estigmatizado como uma prática insolente e nefasta, antissocial, negativa, estas eram as palavras que os militares usavam naquele momento em que as universidades estavam sob censura e sob forte vigilância. Então, sem dúvida nenhuma você tem razão na formulação de sua questão, os dois livros têm diretamente a ver com a experiência da minha geração. Mas mais do que falar sobre a ditadura militar, eu queria mencionar como a ditadura militar era incorporada em outras formas mais difusas do convívio social, por exemplo, a maneira como a ditadura impôs um clima de visão do mundo dualista: ou você está contra ou você é amigo da ditadura. Não há alternativa, não há como pensar fora desse registro dualista. É a lógica da guerra fria, aquela lógica que, por exemplo, foi contestada pela Viena Vermelha. Então, não havia como você pensar fora disso, sem, é claro, cair num estigma de desmoralização e é evidente que, enfim, eu me sentia muito sufocado pelos dois lados. Eu não me identificava nem com a ditadura nem com o pensamento da esquerda autoritário, dogmático e intransigente, e eu fiquei naquela posição de quem tem um nexo mais existencial, situacional com a vida, aquele pequeno grupo humano que no período era caracterizado como desmundado, como bicho-grilo, enfim, esse tipo de estereótipo negativo. É evidente que isso teve um estereótipo muito grande nas minhas opções. Foi por isso que eu escolhi fazer uma pesquisa numa 
área que não tinha espaço institucional no nosso departamento, que era História da Cultura. E foi basicamente difícil pra mim, porque eu não tinha com quem ter interlocução, e por razões óbvias. O que predominava era a História Econômica no momento em que o grande debate acontecia em volta do modelo econômico do Brasil, modelo econômico, tecnocrático, industrialista da ditadura militar, ou então a questão da História Política, no sentido em que o outro grande debate era como criar um caminho para a superação do impasse ditatorial. Então, História Política e História Econômica eram as duas grandes linhas de debate não só na área de história, mas no conjunto da FFLCH, cultura, enfim, era vista como uma questão desviante, alienante e conformista, e era muito doloroso toda vez eu ser confrontado dessa maneira, a ponto de obviamente a certa altura eu não me expor mais, não discutir mais, não dialogar mais com ninguém. Quando então eu entrei na pós-graduação e apresentei o meu projeto, a reação de alunos e professores foi dizer: 'Não, você está errado, esse tipo de trabalho não dá para fazer no departamento de História, não tem nada a ver com o departamento de História, você tem que fazer isso na Letras porque é um trabalho de literatura'. Não tendo alternativa, eu fui fazer na Letras. Fiz alguns cursos lá, e as pessoas me diziam: 'Não sei o que você está fazendo aqui, porque isso não tem nada a fazer com Letras, isso é sociologia da arte, de literatura, você tem que fazer no departamento de Sociologia'. Então, eu fui para o departamento de Sociologia circular e as pessoas me diziam: 'Me desculpe, isso não tem nada a ver, obviamente não é aqui, você tem que voltar para História'. Eu fiz o círculo completo, então voltei e fiz discretamente. A diferença foi que quando eu fui defender o trabalho, a banca era composta de historiadores em grande parte consagrados, e àquela altura independente dessas pressões corporativas, da polaridade da ditadura ou da guerra fria, e que deram uma receptividade excelente para o trabalho e a partir daí ele ganhou uma repercussão fora da universidade e foi de fora para dentro que eu consegui o respaldo que eu nunca tive lá dentro. Hoje em dia provavelmente a área predominante não só no Departamento de História, mas em qualquer departamento de História do Brasil, é História da Cultura. É paradoxal e, enfim, eu fico feliz que seja assim, mas é bom que se compreenda que nem sempre foi assim, e que já foi muito mais difícil conseguir criar uma atmosfera de tolerância e debate equilibrado.

Úrsula: Diante do Orfeu Extático na Metrópole, e diante do diagnóstico esperançoso que o senhor faz no final do Corrida para o Século XXI, como não se envenenar pela perda da individualidade no movimento de luta social coletiva e conseguir conciliar as duas coisas, o movimento social e a criação individual?

NicolaU: Ótima questão. E você tem razão, essa questão se coloca na medida em que eu fiz o loop na montanha-russa, e cronologicamente então, para colocar 
as coisas nos seus lugares, corresponde ao final dos anos noventa. Corresponde ao que estava acontecendo naquele momento, sobretudo em torno da enorme visibilidade e ressonância que estavam tendo os movimentos antiglobalização, as manifestações públicas, grandes manifestações de rua, em Washington, em Seattle, em Vancouver, culminando em Gênova, mas também Praga, Berlim, Londres, enfim, quando alguns desses movimentos apareceram em geral numa posição de confrontação direta contra a Organização Mundial do Comércio (OMG), em particular porque a própria $\mathrm{OMG}$, mais que qualquer outra instituição, cristalizou o significado da globalização como um modo de interação desigual que privilegiava os países altamente industrializados em detrimento dos países subdesenvolvidos, ou em estado de desenvolvimento ou alienados do mercado econômico. Quando cada um desses movimentos se articulava num desses pontos, numa dessas cidades ao redor do mundo, simultaneamente vários movimentos iguais, várias ondas de onda igual, maior ou menor magnitude se desdobravam ao redor do mundo. Nenhum deles aconteceu sem que houvesse uma repercussão em movimentos de rua aqui em São Paulo ou no Rio de Janeiro, por exemplo, para dar apenas esses dois exemplos. Portanto, era um movimento de magnitude mundial, era uma nova maneira de fazer política nos anos noventa e era uma política de rua, de confrontação direta e muito canalizada numa juventude que não tinha compromissos com a linguagem herdade da Guerra Fria e com os partidos herdados da Guerra Fria, era uma política feita no teatro urbano, feita a partir da situação da cidade, do convívio com o ambiente do espaço público, não por acaso nascida de movimentos que pretendiam reconquistar o espaço público que foi paulatinamente sendo ocupada e sufocada por uma urbanização pensada em termos de resolução de vetores de tráfico, de transporte e de comunicação urbana. As cidades foram cada vez mais repensadas em termos de como redistribuir os veículos, e particularmente, veículos particulares, e as praças sendo transformada em estacionamento, as comunidades e os bairros sendo cortados por vias expressas que as pessoas já não conseguem mais atravessar, e quem está de um lado fica de um lado e quem está de outro fica de outro, e a cidade toda sendo cortada e fragmentada e nulificada do ponto de vista da integração social e da vivência cidadã do ponto de vista do espaço público em função dessa versão tecnocrática do urbanismo. Então, não é um movimento que nasceu nos anos noventa, é uma coisa que vem de antes, de uma crítica de um urbanismo antissocial, antidemocrático, desumano e totalmente vinculado a uma visão economicista, produtivista do ser humano, e esse momento que quer negar não apenas o modo como está sendo conduzida a globalização, mas é toda essa concepção tecnocrática e a política de polarização de concorrência entre mundo comunista e mundo capitalista que estava por trás deste desdobramento de lógicas de planejamento alheias ao interesse propriamente humano e social por toda parte do mundo. 
Isso ganhou uma enorme força e se tornou o eixo que mobilizava o debate político, e àquela altura praticamente se desestruturou, desmontou a política convencional herdada da guerra fria, as instituições parlamentares formais, colocou em xeque todo esse mundo imensamente conservador e imensamente caduco, centrado numa tecnologia desumanizante, para colocar o ser humano, o lazer, o prazer, o convívio, o cidadão no centro do debate, de onde nunca devia ter saído. E, assim como a política do prazer foi destruída pela AIDS, essa política do espaço público e do espaço urbano foi destruída pelo atentado de II de setembro e a política voltou novamente para o eixo conservador em que estava, e todos nós estamos novamente cada vez mais afundados numa espécie de rotina desumanizante, que a essa altura não abre nenhuma perspectiva para humanidade. Essa era a razão para que o livro tivesse um final entusiástico, porque ele foi logo antes da queda das torres. Aí me sugeriram 'reveja o livro para colocar um capítulo final sobre as torres, por que senão... aí você dá... senão...'. Aquele livro só faz sentido sem as torres, aquela esperança que está ali só faz sentido antes das torres.

ANNA: Então, pensando nessas questões da metrópole, da cidade, que são muito importantes no seu trabalho, pensando em São Paulo com essas políticas higienistas do tipo Gidade Limpa, lei antifumo, políticas cada vez mais restritivas em institucionalizar os espaços públicos, como você enxerga essa cidade que caminha nessa direção?

ÚrSUla: E daí a gente queria pensar na metáfora do Corrida para o Século XXI, se a gente estava lá no loop, considerando isso tudo como São Paulo está sendo hoje e depois das torres gêmeas, qual é a nossa posição na montanha-russa?

Nicolau: Eu acho que o que essa espécie de gestão normativa da cidade que se articula, sobretudo em torno de códigos proibitivos - não pode isso, não pode aquilo, não pode aqui, não pode acolá - tende a uma espécie de infantilização da cidadania, num mau sentido, não no sentido da Alice, mas no sentido de que a criança tem que ser subalterna a uma autoridade adulta, a uma autoridade mais madura. E aí a autoridade institucional seria essa autoridade mais madura e o cidadão é essa criatura infantil que tem que ser conduzida pela mão e tem que ser dito 'isso pode, isso não, larga, nenê, que isso é caca' e assim por diante. Obviamente, é uma forma profundamente antidemocrática e de esvaziamento da substância da cidadania. É claro que a magnitude do crescimento de São Paulo tende a pensar que a alternativa possível é essa cidade submetida a uma gestão centralizadora, centralista, verticalizante e tutelar sobre os cidadão e a vida pública, e eu acho que é o oposto do que deveria ser. Acho que justamente porque é uma cidade tão grande e cada área dela tem características, particularidades, 
interesses e necessidades entre outras áreas, a gestão deveria ser altamente descentralizada, altamente delegada para cada comunidade poder ter a gestão de suas próprias necessidades, de seus próprios elementos estruturantes, das suas próprias aspirações, de modo que os recursos do conjunto da cidade pudessem ser alocados em função dessas diferenças, e não de uma política unitária que obviamente não vai ser da mesma maneira a todas as partes. Mas como sempre, há um pequeno núcleo centralizador de privilegiados, por isso eu vejo esse urbanismo pedagógico, normativo, que nome se dê a ele, com enorme desconfiança, com enorme suspeição, e como uma prática desmobilizadora e despolitizadora da cidadania. Você pergunta que altura estaria do loop, a minha metáfora do loop ela é uma metáfora sobre o efeito que a tecnologia tem na capacidade de reflexão do ser humano. A tecnologia é tão acelerante e tão agenciadora da percepção, da sensibilidade, do comportamento humano, que você tende a se entregar a ela sem refletir, e por isso você adere conformisticamente a ela e deixa-a conduzilo para onde ela quiser, como se ela tivesse vida própria. $\mathrm{Na}$ verdade, não tem vida própria, ela é o resultado de uma gestão de pequenos núcleos que são os que têm o poder de decisão sobre o processo tecnológico, e se você cede a esse processo, e se você se conforma às suas rotinas está cedendo o seu espaço de autonomia para aquele pequeno círculo decisório. Então, uma vez mais eu acho politicamente supernegativo e desmotivador, e uma contingência que esvazia no sentido mais substantivo da cidadania. A minha ideia do loop é justamente que a gente não deve se render à tentação de se largar na montanha russa, que é tão atraente e é tão sedutora, mas ao contrário, tentar ver o mundo com a mão no breque. Tentar entender para onde as coisas vão e quão possível foi para você participar das decisões que estão definindo a sua vida e a vida dos outros. Se a gente não entender claramente o que está posto em jogo e qual é a melhor alternativa, a gente estará sendo arrastado para interesses que não são os nossos e para um destino que beneficia outras pessoas e outras fontes que não as vítimas desse processo tecnologicamente cego.

Fernando: Professor, retornando ao contexto da Primeira República, temos Euclides da Cunha e Lima Barreto realizando Literatura como Missão. E durante a leitura do livro, eu não consegui pensar em outra coisa senão o momento da ditadura e os músicos daquele momento tratando a 'música como missão'. E hoje eu gostaria de perguntar para o senhor se existe ainda algum ramo da cultura no Brasil que esteja desempenhando este papel.

NicolaU: Excelente a sua leitura, eu nunca tinha percebido dessa maneira, agora vejo que sim, que tem a ver. O que eu pensava de uma resistência pública política centrada nos escritores, no período dos anos I970 e I980, era muito mais centrada na comunidade artística dos músicos, dos grupos de teatro, você 
tem total razão. Foram eles certamente a minha inspiração no mesmo sentido que o Lima Barreto, o Euclides da Cunha e o Machado de Assis possam ter sido. Aí o outro lado da questão é mais perturbador. Ok, eles não prevaleceram, mas eles estavam lá. Houve pelo menos uma parte da comunidade que se sentiu tocada e profundamente motivada e esclarecida por esses escritores e que certamente procurou fazer uma aposta no mesmo sentido do que eles propunham, embora minoritários e vencidos na história, eu pude falar dessa experiência e falar do grande mérito que tinha como pensamento crítico e humanizante no mundo repressivo e antissocial, e da mesma forma, é claro, na ditadura houve aquele momento glorioso de se articular uma comunidade de resistência de ideias muito claras, muito vivas e muito apaixonantes em torno do espírito de resistir contra a brutalidade, contra o obscurantismo, por meio das ideias, da preservação do princípio da felicidade, do prazer, do experimentalismo da vida cotidiana, dos comportamentos na vida cotidiana. A parte final da sua pergunta, que é extremamente difícil de responder, delicada e desagradável, é 'e hoje, o quadro é o mesmo?'. Eu sinto um nó na garganta para dizer que eu não sinto isso com a mesma forma, nem como foi na primeira República, nem como foi nos anos I960 a I980, porque o que prevalece é uma maré de consumismo e de espetáculo que obtém a adesão maciça, você tem pouquíssima resistência a isso, em especial em blocos que não estão mais no âmbito do mainstream - como dizer isso em português - da corrente central, em áreas muito mais periféricas, por exemplo, na cultura popular, nos grupos funk, nos grupos de Black music, nas periferias da cidade, gente vivendo experiências muito mais dramáticas, muito mais trágicas e que, portanto, são possíveis de ver a sociedade com o desinvestimento dessa fantasia manipulatória do espetáculo e do consumo, porque não são parte dele. Mas no conjunto, aquele que aparece refletido na mídia de uma forma geral, aquele que ocupa a percepção e a visibilidade de todos, em todos os cantos e em todas as esferas do cotidiano, o que você vê é uma espécie de conformismo passivo a essa fúria de identificação, de modernidade, com a apropriação, acumulação, privilégios, como que se esse fosse o objetivo da vida e fosse trazer felicidade e bem-estar da sociedade, e outros ideais como da igualdade, da fraternidade e da liberdade que foram o fundamento da criação da sociedade moderna na revolução norte-americana e na revolução francesa hoje soam como piada de mau gosto, o que é profundamente lamentável, aterrorizante.

Fernando: Como é que o senhor enxerga a literatura hoje tendo que competir com outros veículos de cultura e comunicação como o cinema, a TV, a internet?

NicolaU: Uma vez mais eu tenho a sensação é que a literatura não está na situação de competir, ou não está na situação de resistir ou sequer de resistir, 
na verdade o que você vê, enfim, no que é que tem mais visibilidade da literatura é uma adesão completa a esse mundo do consumo e do espetáculo. A literatura hoje é definida pela lista dos 'dez mais', então você é grande literato se você está nos 'dez mais', se não você não é parte, você não aparece em lugar nenhum, e aí você pode ser o mais medíocre dos escritores, mas se você está entre os 'dez mais', você vai estar na capa das revistas, vai ter entrevistas nos jornais, vai ter um enorme destaque de televisão, de impressão etc.

RicARDo: Agora entramos no momento sociedade do espetáculo e sociedade dos excluídos. O YouTube é uma nova ferramenta de expressão cultural. $O$ vídeo mais assistido é $B a d$ Romance, Lady Gaga, e em seguida vêm as versões mais variadas tomando-o como matriz. Isso nos remeteu à questão da reprodutibilidade da arte levantada por W. Benjamim. Quando assistimos às versões caseiras no YouTube, vídeos que foram feitos sem o dedo da indústria, nos identificamos por vermos como foi feito: sem truques, sem edição, a vida acontecendo ao vivo como se a gente estivesse ali. O YouTube pode ser considerado uma forma de redemocratização da arte?

Nicolau: O YouTube abriu um espaço de espontaneidade e intromissão, invasão, no espaço controlado da mídia por gente que estava fora, por ideias que não circulam e atitudes que não são aceitas, e por meio dessa quase que pirataria, dessa possibilidade de uma atuação independente, num circuito que até agora não está sob completo controle, você pode subverte as regras, você pode contrariar o senso comum, você pode dar uma cambalhota nos sistemas de controle. E eu acho magnífico. Evidentemente, os dois potenciais estão lá, porque pode ser uma mídia que pode ser usada para acentuar esse processo de homogeneização do comportamento e da mentalidade. Tecnologia nunca tem por si só uma definição, quem controla a tecnologia ou quem é capaz de entender e jogar com as decisões é que pode encaminhá-la numa direção ou na outra. Mas a gente vive ainda um momento de tensão em que essas mídias são relativamente recentes e elas apareceram numa situação em que vieram de baixo para cima, sem estarem submetidas a um enquadramento unificador. O que as instituições, as grandes empresas, os governos desejam produzir cada vez mais, é produzir esse efeito do enquadramento, é diminuir o espaço da liberdade, o espaço da espontaneidade. Por enquanto, a luta está de igual para igual, se não vier uma AIDS tecnológica ou um II de setembro tecnológico que mude completamente, eu acho que ainda é um dos poucos espaços de liberdade que a gente pode hoje em dia usar como forma de infiltração de ideias subversivas e de comportamentos inesperados, surpreendentes e desestabilizadores. Eu adoro experiências feitas com essas mídias e com esse teor subversivo, e outra vez um efeito positivo da globalização, porque isso não acontece apenas no nosso 
espaço, apenas nesse país ou nessa cidade, acontece no mundo como um todo, o que torna ainda mais promissor e mais vibrante esse contexto por enquanto.

RICARDO: Nós podemos dizer que a repetição deixa de ser uma repetição pelo fato da matriz, que seria o vídeo da Lady Gaga, produzir outros objetos individualizados, particulares?

NicolaU: Então, isso é uma teoria interessantíssima que eu acho que foi formulada pela primeira vez pelo... Vocês se lembram aquele psiquiatra de Harvard que passou a fazer experiências com LSD e foi expulso... Timothy Leary que primeiro identificou essa tendência que a mídia funciona por memes que são como vírus que você solta e que vão se multiplicando e criando força até virar um fato de proporções que define políticas, comportamentos, decisões. Nesse sentido, eu acho que o potencial de recursos como a internet, ou mais especificamente o YouTube, como você estava se referindo, são exatamente politizáveis por meio dessa prática de geração de memes ou de vírus e que você pode filtrar. Você puxa alguns padrões dominantes da mídia e distorce o padrão, você faz aquilo que os situacionistas chamavam de bouleversement, dá a ele um sentido cômico ou paródico ou irônico ou sarcástico, e o que era para ser visto de maneira conformista, passa a ser visto de maneira subversiva. Você joga isso na mídia e conforme o potencial criativo da maneira como faz isso, isso ganha uma enorme ressonância a partir do ponto em que todo mundo entra em sintonia com isso e a situação anterior passa a ser vista às avessas do que era antes. Então esse é o potencial e a grande estratégia do modo como você pode usar inteligentemente a internet e o YouTube.

RICARDO: Existe um movimento global contemporâneo de dar voz aos excluídos dentro da sociedade do espetáculo. Os excluídos de ontem são os incluídos de hoje. A cultura contemporânea funciona por meio dessa dialética de inclusão e exclusão?

NiGOlAU: Então, quando a inclusão do excluído se torna compulsória, ela passa a ser parte do mesmo sistema que define o que está dentro e o que está fora. Essa é para mim a restrição que eu tenho com relação a essa ditadura do politicamente correto. Então, o que há de errado para mim com o politicamente correto é que ele é absoluto, e ele é autoritário e intolerante, você não pode estar fora dele nem um milímetro. É IOO\% dentro dele, é um estado de convicção devocional e não se tolera qualquer tipo de crença alternativa. Portanto, passa a ser tão opressivo como qualquer forma de ideologia autoritária, assim posto dessa maneira. Eu acho que a questão da exclusão passa a ser negada quando formulada assim, porque o que era exclusão passa a ser a nova ditadura. Eu acho que há na exclusão 
uma ética do decidir ser, do desejar ser por parte do excluído quando a questão é politizada. Então, se você vê uma sociedade indígena e você diz 'as sociedades indígenas são excluídas e o modo de inclusão é aceitar completamente essa sociedade indígena como parte do conjunto ou da diversidade ou da pluralidade - é a palavra chave que se usa hoje em dia' você está pondo a sociedade indígena num nicho que é o nicho que ela vai ocupar dentro dessa colmeia dessa diversidade. E, no entanto, vista fora dessa lógica, ela não é apenas um nicho numa colmeia, ela é uma totalidade, ela tem outra lógica, se articula por outros valores, ela tem outro quadro de referências, outro quadro imaginário e a única maneira de compartilhar esse imaginário é saindo do seu e entrando nele. Portanto, ele só funciona na sua dinâmica própria quando ele se mantém na condição excludente, quando ele não se deixa reduzir a uma homogeneização que vai 'reespaciá-lo' num mapa predefinido e resolvido de uma diversidade que será a mesma para todo o sempre. Uma vez eu vi essa questão colocada brilhantemente pelo meu grande colega, o professor Jean-Claude Bernardet, da escola de comunicações de Cambridge, e ele estava justamente falando, acho que o assunto era uma entrevista na televisão, e o assunto de fundo era a Parada Gay, participar ou não da Parada Gay, alguma coisa assim; ou seja, a cultura homossexual ser transformada em mainstream e ele disse que ele fazia questão de, como pessoa, como ser humano, ter adotado uma sexualidade que traz consigo uma ética da transgressão, e que ele quer viver como a ética da transgressão, e que ele não quer ser posto na norma, que ele quer viver numa fronteira, num limite, num limiar, onde ele não tenha controles de regras, de fórmulas predefinidas de comportamento ou de estados de alteração emocional ou afetiva, de forma que ele se sinta livre para fazer daquela sexualidade uma invenção criativa da vida dele que não tenha que estar codificada ou estabilizada por qualquer estereótipo dentro de uma sociedade definida por um pluralismo em que, na verdade, é uma vitrina de diferentes, como uma loja de doces de diferentes sabores, cada um tem um sabor próprio. Ele quer ser uma incógnita, ele quer ser algo não redutível a qualquer espécie de rótulo ou fórmula e que exista no estado de permanente transgressão de toda e qualquer regra como um momento de liberdade absoluta. E nesse sentido ele não queria compartilhar de um status de participante de uma mainstream, de uma política dominante, ou de um código do politicamente correto. Aquilo para mim foi imensamente inspirador, porque como membro de uma identidade homossexual publicamente assumida, ele constrói essa identidade como um código de autonomia que não está sujeito ou que ele não quer ver sujeito a qualquer forma de redução a práticas políticas normativas que venham de fora. Eu acho de uma riqueza absolutamente prodigiosa essa posição, eu fecho com ela, é assim que eu compreendo também que deva ser a política de identidades, como uma política de autonomia e de liberdade e não de rotulação, normatização e de uma pluralidade previsível... 
RicARDO: Ao mesmo tempo em que os alunos adoram as suas colocações, reclamam por ouvi-lo pouco, por ouvirem mais os outros alunos durante os seminários, que, em sua opinião, são sempre os melhores momentos da aula por serem a própria História. A História dos outros. Sua própria visão da História é calcada nos excluídos, esses são os verdadeiros agentes do processo histórico, pois é sempre contra eles que vem a reação. Como se dá essa sua revolução metodológica calcada nos personagens do lado de fora da História, como os cipaios, os boêmios, os alunos?

NicolaU: Então, não é claro que a gente vá colocar os alunos como uma categoria de excluídos, na medida em que aluno de uma escola pública de alto nível, como é a Universidade de São Paulo, compartilha de uma condição de privilégio. Mas o que eu acredito que você está pondo em jogo é uma questão da voz, dentro daquela instituição prestigiada: qual voz deve prevalecer? A voz de um estamento abstrato, que a gente chamaria de a tecnologia e a ciência, ou a voz de seres humanos concretos, sujeitos sensíveis historicamente condicionados e circunstancialmente definidos, que são os professores e os alunos. Eu acho que a tendência da instituição é a de subsumir o conjunto da universidade dentro desse abstrato, em que os professores representam a ciência e a tecnologia, e a voz deles é a voz da ciência e da tecnologia, e aos alunos cabe serem absorvidos, ao ponto em que só poderão articular sua própria voz quando estiverem dentro desse estamento depois de formados ou depois de qualificados nos mestrados e doutorados. De forma que eu acho que, particularmente sendo professor de História, e Historia da cultura, o que me parece mais rico é aproveitar as aulas de História da cultura para fazer uma metacrítica dessa instituição, tentar sair dela e vê-la de fora para dentro e entender como ela funciona e perceber que ela tem uma vocação fortemente autoritária, arrogante e castradora de vozes e posições alternativas que não se deixem subsumir nesse abstrato institucionalizante da grande ciência e da grande tecnologia. Então, cada professor ali é um ser humano com sua própria história de vida, com suas próprias escolhas, com suas próprias limitações, com a sua própria bagagem de conhecimento e cada aluno tem as contingências que o cercam, cada geração de aluno traz contingências diferentes, então a situação da sala de aula pra mim funciona com uma espécie de teatro experimental, onde você põe em jogo a circunstância da instituição com a circunstância do professor e a circunstância geracional dos alunos presentes e o convite é para que todos possam se ver de dentro pra fora e perceberem, portanto, quais são os seus limites, quais são os códigos pelos quais têm a sua voz travada ou tolhida por uma série de conceitos generalizantes que desumanizam professores e alunos dentro de uma instituição que, em princípio, seria algo mais e acima do que seres humanos comuns. A universidade deve, do meu ponto de vista, ser uma praça pública, como a Ágora grega, em que todos discutam 
com a mesma possibilidade, com o mesmo grau de participação e o mesmo valor da sua palavra, a partir da posição em que estão o que é que está sendo posto em jogo em cada informação, em cada conhecimento nos compromissos que eles trazem consigo e nos encaminhamentos das decisões que eles impõem para que se possa avaliar se elas são, de fato, as melhores, se elas, de fato, correspondem às expectativas atuais das novas gerações ou do que seja bom ou melhor para o destino e o futuro desse país, eventualmente. É nesse sentido que eu acho que tenho a tendência a enfatizar a participação dos alunos e a solicitar que eles tragam não uma reprodução do conhecimento que extraem dos livros para a sala de aula, mas que tragam as experiências da sua vida, as expectativas, os desejos, as fantasias do seu momento, da sua geração, da sua circunstância pra dentro da sala de aula, e a gente faça daquilo uma reflexão coletiva sobre o que é que nos anima, o que é que nos excita, o que é que nos atrai, o que é que nós rejeitamos, o que é que nós não queremos, e em função desse confronto, que tipo de profissional historiador, que tipo de educador, que tipo de professor, que tipo de intelectual a gente sente que cabe formar a cada momento, a cada geração nessa sociedade paulista brasileira contemporânea.

RicARDo: A História continuará a ser ditada pelos excluídos até, em vez de serem exterminados e silenciados, forem ouvidos? Como a História Contemporânea é um processo permanente de repressão, o que o senhor acha que pode acontecer?

NicolaU: É óbvio que eu sou historiador e não futurólogo. Minha especialidade é o passado, mas sempre cabe poder cogitar sobre o futuro, tem que refletir retrospectivamente e aí, quem sabe, o historiador possa ser um agente útil. E pensando nesses termos, acho que não é porque existe um discurso político dominante hoje em dia de inclusão dos excluídos que essa inclusão de fato vá haver. Lembro-me do período da ditadura, a conversa era "vamos deixar o bolo crescer para que depois possamos repartir a prosperidade com todos" e um pouco do discurso a respeito dos excluídos. Hoje em dia tem essa conotação populista: vamos incorporar um pouquinho de gente a mais a cada vez, até o ponto em que lá adiante a gente possa estar incluindo a maioria, e quem sabe a totalidade. É uma espécie de uma situação de jogar para adiante, jogar paras outras gerações as decisões que não se quer tomar agora, porque se se quer construir uma sociedade democrática é preciso cogitar e produzir praticamente as instituições de uma sociedade democrática, que está longe de ser o caso da sociedade brasileira. Então, eu acho que esse discurso inclusivo é um discurso populista. O fundamento do populismo era exatamente esse, era uma máquina eleitoral, se a gente pegar o populismo do pós-guerra, representado aqui em São Paulo por essas duas figuras icônicas, o Ademar de Barros e o Jânio Quadros, cada qual propunha 
uma política de ampliação da participação, o Jânio Quadros, sobretudo da classe média e classe média baixa, e o Ademar de Barros, sobretudo do operariado e de setores do funcionalismo. O que cada qual propunha era progressivamente e abrindo mais e mais a sociedade às oportunidades econômicas, às oportunidades de ascensão social, às oportunidades culturais para setores maiores da população, e quando as pessoas votavam no político populista, elas não votavam numa política que listaria a garantia de maior participação e de melhores oportunidades, mas na esperança, na expectativa das palavras prometidas pelo político populista. Então, o que é o populista? É o negociador da esperança, um negociador da expectativa. Você cria a expectativa e transforma a expectativa em voto. E eu acho que essa é a forma dominante de fazer política no Brasil no pós-guerra antes e depois da ditadura, você constrói cenários imaginários, e vai angariando simpatias por meio do modo pelo qual você amarra as pessoas a um projeto que é uma esperança que se perde na fumaça de um futuro infinito e imprevisível. Isso significa o descompromisso com a criação de estruturas autenticamente democráticas agora, já. Um caso de impacto pra pensarmos essa situação é a questão do ensino: você pode criar montes escolas, pode criar escolas com teatro, com piscina, com teatro pirotécnico ou o que imaginar, mas se a qualidade de ensino não for boa, pouco importa se o aluno vai conseguir chegar até o segundo grau ou não. O fato é: ele vai sair da escola semialfabetizado ou analfabeto como é a situação que se vê na condição crítica do ensino hoje em dia por todo o país. Então, se você quer construir um mundo melhor, com maiores e melhores oportunidades, maior e melhor inclusão social, você tem que efetivamente produzir estruturas que realizem uma educação pública de qualidade. Não há outra maneira de obter promoção social, promoção cultural e econômica que não seja por meio da educação. Educação é a mais radical das políticas, e se você deixa em segundo plano, se deixa em terceiro, em quarto, em quinto plano, se na hora em que tem que fazer cortes no orçamento por uma situação de crise o primeiro orçamento que você vai cortar é o da educação, obviamente você é um manipulador de perfil populista no estilo que foi definido no pós-guerra pelo ademarismo e pelo janismo.

Fernando: Estamos em época de Copa do Mundo e ela é fascinante porque algumas partidas parecem extrapolar as fronteiras do esporte. No Brasil, é a única vez, se eu não estiver enganado, em que as pessoas realmente se sentem brasileiras. Os olhares do mundo se voltam para o país-sede, o que ele tem a oferecer e como vai se desenrolar o evento. Seria a Copa do Mundo, assim como a Olimpíada, uma nova Feira Internacional?

NicolaU: Então, não há dúvida que é esse conluio entre o esporte e o espetáculo. O que é muito conveniente, porque o esporte moderno não tem 
a ver com o que a gente tendia a entender como esporte na antiguidade. Por exemplo, no festival dos Jogos Olímpicos na Grécia Antiga, que era um festival eminentemente religioso, e o que se queria ver no festival era o modo como os atletas encarnavam potenciais divinos e é esse o sentido místico da Olimpíada para os gregos. Quando se inventam os esportes modernos, em meados do século XIX, eles estão orientados para outra direção, uma fórmula de produtividade, é o desafio do ser humano com os limites do seu próprio corpo. Quão mais você pode definir o desempenho, o reflexo muscular nervoso dentro de um limite espacial, dentro de um limite de regras e dentro de um limite cronológico. Então é o ser humano disputando com seus próprios limites, ou individualmente ou em equipe, para um efeito que é um efeito de produtividade: quem rende mais, quem rende melhor. E hoje em dia no futebol, por exemplo, tudo está reduzido às estatísticas. A gente vai assistindo às partidas de futebol e os narradores vão dando estatísticas sem parar, o tempo todo. Tudo é estatística. E aí, no final, quando sai a súmula do jogo, são estatísticas: quem teve mais escanteio, quem teve menos, que fez mais falta e assim por diante. Então é um universo que é um universo estatístico, da redução matemática do dispêndio físico, do desempenho humano no sentido de uma melhoria, um incremento cada vez maior da capacidade, do dispêndio físico dos atletas. Que é um modelo, obviamente, da indústria. Não por acaso o homem que definiu o sistema da linha de montagem, em que os movimentos físicos necessários para cumprir as tarefas que culminariam na montagem de um automóvel eram reduzidos a movimentos básicos. Cada operário fazia uma série contínua desses movimentos, e assim por diante, de forma que o que ele fez foi reduzir o trabalho a uma série de fórmulas de ação física divididas analiticamente e reduzidas a um padrão estatístico. Não por acaso esse homem era um especialista em esportes, ele escreveu um manual de treinamento de tênis e um manual de treinamento para alpinismo, antes de construir o modelo da linha de montagem. Então, é muito nítida a relação que há entre o esporte e a preocupação com a produtividade do trabalho, e nesse sentido o esporte moderno subsume essa lógica da sociedade capitalista, cujo valor supremo é o trabalho e, em particular, a produtividade do trabalho, o quanto se pode despender do trabalho num determinado limite de tempo. Nesse sentido, você olha para o futebol com uma expectativa de um efeito eufórico, que é o da vitória da sua equipe, mas no processo incorpora a lógica, a sintaxe de educação para uma pragmática da produtividade que está embutida intrinsecamente na maneira como o jogo é articulado. E à parte dessa vinculação entre o futebol e o sistema tecnológico e econômico, há uma vinculação, evidentemente, entre o futebol e a lógica do espetáculo. Criamse diferentes ligas e a liga que conta são as ligas especiais: a primeira liga, a primeira divisão, ou que nome se dê, em diferentes países diferentes nomes, série A na Itália, e assim por diante. O que quer dizer isso? Quer dizer que não 
é a sua empatia com o seu time local, aquele time no qual você joga no seu bairro onde os seus irmãos jogam, seus conhecidos, seus parentes, seus amigos, seus vizinhos, seus paroquianos jogam, não é esse o futebol que conta. O futebol que conta é o megafutebol, das megaestrelas, dos mega-atletas, aqueles que têm salários astronômicos, justamente porque são aqueles que dão o referencial para essa produtividade no seu nível mais exacerbado. E o futebol, como os demais esportes, virou essa espécie de sistema de Hollywood, sistema de estúdios nessas competições internas, dentro dos países, das suas ligas dominantes, e depois nas disputas regionais e nas disputas internacionais que culminam com a Copa do Mundo. E esse espetáculo, portanto, vai crescendo. Ele tem um público que é progressivamente maior quanto maior é a concentração dessas megaestrelas e aí culmina nessa Copa do Mundo com o fenômeno das figurinhas, em que você tem que colecionar as figurinhas e que vão, no processo de montar o álbum, te tornar íntimo, particulares da vida de todo e qualquer atleta da seleção de Gana, da seleção da Sérvia, ou da seleção da Dinamarca, ou da seleção da Argentina, ou do Uruguai, o que seja. E isso dedicado para crianças. Portanto, incorpora nas crianças desde bem cedo essa vinculação com essa lógica espetacular de um futebol transformado num megaevento que concentra um investimento de capital de uma magnitude que seria capaz de transformar qualquer sociedade do mundo numa potência. E o espetáculo ganha uma dimensão midiática que também faz dele o show midiático que tem o maior público global no planeta Terra. Ou seja, em termos de expressão da força do capitalismo, provavelmente o futebol, hoje, ocupa o topo do vértice central do sistema e é a máquina que mais consolida esse sistema. A gente tende a ver outra dimensão do futebol que é essa dimensão festiva, eufórica, de você vibrar e carnavalizar, fazer barulho, fazer ruído, se vestir de uma fantasia aparatosa. É o lado vitrine, é o lado que seduz, porque se você fosse se concentrar só no treinamento dos atletas, se fosse se concentrar só nas estatísticas, seria realmente tedioso. Como em grande parte se tornou tedioso ver a própria partida de futebol, porque é muita competição de estratégias definidas por sistemas de treinamento e de disciplina tática que não variam muito durante o conjunto da partida e que não dão muito espaço para criatividade individual. Então, tornam a partida meio chata e aí, mais do que a partida, é motivador você ficar vendo o comportamento do público na plateia, as fantasias, a festa, a euforia e o futebol, então, está mais fora, no estádio, do que, de fato, no campo, onde você tem soldados travando uma guerra, simbolicamente. E a festa está toda lá na plateia, do lado do campo, obviamente, e do lado da torcida por trás das telas por todo o mundo. E aí se completa o espetáculo, o lado sedutor, o lado prazeroso, o lado desejante, quão o lado disciplinante, o lado redutivo e estatístico num outro contexto.

É, também, uma metáfora da vida contemporânea. Nesse sentido, o futebol é transparente, ele é revelador. Num mundo fortemente controlado, previsível e 
sem espaço para qualquer espécie de surpresa. O conjunto do time está reduzido a esta espécie de disciplina tática. Se alguém fizer o seu carnaval particular, desestabiliza a disciplina tática. Não é bom para o time. Então, o time tende a ser repressivo com quem é muito inventivo, porque ele está solapando o que todo mundo treinou tanto tempo como uma coordenação coletiva, que não tem muito espaço para o individual. Então, quando o sujeito dá um chute de longe e marca o gol, todo mundo aplaude: "ah, marcou o gol! Fantástico! O gol mais bonito da Copa! Foi de longe e não se faz mais gol de longe!" Mas se ele erra, por pouco que seja que ele errou o gol, vão dizer: "Ah, podia ter passado pra esse ou passado pra aquele", ou seja, volta a disciplina tática: "porque você não fez a disciplina tática?" Enfim, quando dá certo a criatividade, todo mundo aplaude. Mas, no fundo, no fundo, como ela não tende a dar certo sempre, a pessoa vai ser criticada por não estar tendo um comportamento, que é a razão pela qual o Dunga escalou esse time de gente disciplinada, de gente que obedece, de gente que não vai sair do parâmetro.

RicARdo: Professor, agora que estamos nos encaminhando para o final da entrevista, gostaríamos de fazer uma última pergunta sobre essa relação sociedade-espetáculo-mito. Cada época adota um conto de fadas particular. Durante quase todo o século XX foi o da Cinderela, o American Dream, a menina pobre que deseja entrar no espetáculo do baile e ficar rica. Depois vem o Peter Pan, a eterna juventude. E o mesmo acontece com Shakespeare: $\mathrm{O}$ ciúmes de Otelo enlouqueceu os românticos, depois as hecatombes nucleares e o existencialismo trouxeram Hamlet para a boca de cena, com todos os seus questionamentos do que é ser ou não ser humano. Nos anos 60, todos os jovens foram para as ruas, os Capuletos, os Montéquios, enquanto Romeu e Julieta foram juntos para o cinema. Qual é o próximo conto de fadas, ou a próxima peça do Shakespeare, que vamos adotar?

Nicolau: Hum!... A minha inclinação é nunca tentar conceber uma espécie de padrão a partir do qual você possa homogeneizar um conjunto. A minha inclinação pessoal é dar fragmentação, criando uma multiplicidade que não tem centro e que não tem periferia, em que as coisas tenham espaço para crescer da maneira mais diversa, inesperada e incontrolável possível. E aí a metáfora literária que me vem é As Flores do Mal, do Baudelaire. Acho que o que falta, e o que eu gostaria de ver crescendo por toda a parte são flores do mal nesse sentido e não do mal definido biblicamente, mas do mal no sentido daquilo que não está no padrão, daquilo que não está no senso comum, que não está na conformação com o quadro vigente de valores e comportamentos na medida em que cada pessoa possa fazer da sua vida uma autêntica experiência de limites, de testar os seus limites, de testar seus potenciais, de testar o seu desejo nas 
mais imprevisíveis direções e possibilidades. E o lado que eu acho mais trágico e acachapante da nossa sociedade é que ela tende ao contrário disso, é que ela tende à padronização, ela tende à conformação, ela tende à homogeneização por um efeito do modo pelo qual publicidade se tornou a prática dominante. Até processos tão cruciais como eleições presidenciais são definidas por práticas de marketing, por decisões de merchandising político. Nesse sentido, a sociedade vive sob jogos de manipulação por meio dessas estruturas midiáticas que penetram em todos os âmbitos do público até o mais intimamente privado. E o que eu, obviamente, gostaria de apostar é na possibilidade de a gente, de setores da sociedade conseguirem se desprender dessa estrutura midiática e mercantil dominante e tentar reconquistar o espaço público, o espaço da vida, o espaço da experimentação, o espaço do prazer, o espaço da felicidade, reinventar essa felicidade, que não tem fórmula, para cada pessoa ela vai ser diferente, para cada pessoa ela vai ter outra dimensão, outra concepção, outra substância. Por isso, o que me parece é que se a gente devesse ter alguma espécie de uma fonte de inspiração, não deve ser uma fonte de inspiração para alguma espécie de mito unificante, mas para uma espécie de inspiração multiplicadora, diversificadora e libertadora em todos os níveis, em todas as dimensões possíveis. É nesse sentido que eu me sinto particularmente gratificado com essa pesquisa que estou fazendo sobre o trabalho do Hélio Oiticica, que viveu essa situação até as últimas consequências, pela qual ele pagou um preço muito caro. Mas, enfim, se não fosse gente como ele, a gente acharia que isso é impossível e ele mostrou que é plenamente possível. Eu acho que se tivesse que acabar com alguma metáfora, acabava com a metáfora de As Flores do Mal.

"Que sua vinda seja um mergulho permanente na Toca do Coelho.

Quanto mais fundo, mais maluco, mais divertido, mais confuso e mais feliz!"4

4 Dedicatória do Prof. Sevcenko num exemplar de sua tradução de Alice no País das Maravilhas ao sobrinho do Ricardo, Enzo H. Cardoso, que estava nascendo no exato momento da entrevista. 